\title{
AN ASSESSMENT OF METEOROLOGICAL CONDITIONS IN AKURE, ONDO STATE, NIGERIA
}

\author{
Francis Olawale Abulude ${ }^{1,3^{*}}$, Mohammed Mohammed Ndamitso ${ }^{1}$ \\ Yahaya Ahmed Iyaka ${ }^{1}$, Aishatu Abdulkadir ${ }^{2}$ \\ ${ }^{1}$ Department of Chemistry, Federal University of Technology, P.M.B. 65, Minna, Niger State, Nigeria. \\ ${ }^{2}$ Department of Geography, Federal University of Technology, P.M.B. 65, Minna, Niger State, Nigeria \\ ${ }^{3}$ Science and Education Development Institute, Akure, Ondo State, Nigeria
}

\begin{abstract}
The aim of the study was to assess the meteorological conditions of Akure, Ondo State, Nigeria. The data was obtained at the observatory unit of the Federal University of Technology, Akure. The observation was made for a period of six months. The results were subjected to statistical analysis. The avearge results of the rainfall ranged from 0 (no rainfall) to $11.60 \mathrm{~mm}$, the average speed $(\mathrm{m} / \mathrm{s})$ ranged as follows: $0.26,0.28,1.09,1.41,0.26$ and 0.41 (July, August, September, October, November and December respectively), the temperature recorded in the months were high mostly $>25^{\circ} \mathrm{C}$ and the relative humidity in all the months ranged from 51.78 to $91.24 \%$ with low standard deviations. Statistically, most of the parameters were negatively correlated. From the results obtained for rainfall, temperature and relative humidity, it could be deduced that there was scanty rainfall. This observations could have serious effects on farm produce and human health.
\end{abstract}

Keywords: Meteorology, rainfall, relative humidity, pollution, prediction

\section{Introduction}

Meteorological parameters are useful in identifying the source of pollutants, also assist in predicting air pollution events (inversions and high-pollutant concentration days) and help stimulate, predict quality of when computer models are employed and help in the understanding of chemical reactions that occur in the atmosphere (Queensland Government, 2015). According to Hogan (2014), meteorology is the scientific study of the atmosphere and physical processes of interaction with the Earth's crust, oceans and outer space. The parameters measured are: precipitation, temperature, wind velocity, barometric pressure, humidity, sunlight and the gradients and interactions of each variable, as well as their temporal variability. The majority of Earth's observed weather is located in the troposphere.Also, the relationship between meteorology and agriculture is important, because agricultural activities depend largely on weather (Vijayan et al., 2013). Essentially, if Agro-meteorological is made use of effectively, the quality and quantity of agricultural production are high, which in short term reduce the production cost. According to Vijayan et al. (2013), meteorological parameters have influence in the physical growth and yield of wheat. Again, Hussain and Mudasser (2004) showed that increase in temperature has an impact of agricultural crops in the mountainous areas, while Pratley (2003) also showed that rainfall has an impact on dry-land yield fluctuations.

A number of natural environments like topography, sun angle exposure, latitude, soil type, vegetative cover as well as the host of factors that comprise the wider area meteorology: cloud cover, regional precipitation, high altitude wind characteristicsand man-made circumstances affect microscale meteorology.

Meteorological factors have many applications in ecosystem, energy generation, transportation system and environment. In the environmental monitoring, they are important in the study of air, noise, thermal pollution and several other environmental phenomena.

* F. O. Abulude (Corresponding Author):

${ }^{1}$ Department of Chemistry, Federal University of Technology, Minna, Niger State,

Nigeria. ${ }^{3}$ Science and Education Development Institute, Akure, Ondo State, Nigeria.

Tel: +2348034458674, E-mail: walefut@gmail.com
Geliş (Received): 08.08.2018

Kabul (Accepted): 07.12.2018

Basim (Published) : 31.12 .2018 
Most studies in the literature (Yamazaki et al., 2015; Yu et al., 2013; Hosseinibalam and Hejazi, 2012; Xiao et al., 2013, Sarasamma and Narayana, 2014; Wang et al., 2012; Manousakas et al., 2013; Crilley et al., 2014; AbuAllaban and Abu-Qudais, 2011) reported weather conditions from India, USA, Iran, Japan, Kenya, Australia, Greece, Saudi Arabia and Jordan. Reports from this part of the world are scarce and this informed the reason for embarking on this research. In the light of the above, the purpose of study was undertaken to assess the meteorological conditions of Akure, Ondo State, Nigeria. The information gathered will be used for proper plannings or mitigation against disasters in the agricultural, transportation, environment, and health sectors.

\section{Methodology}

Akure is regarded as the largest city in Ondo State and it is the capital of the state. It is situated in south-western part of Nigeria. The city has a population of 421,100 . The people are of the Yoruba ethnic group. The geographical coordinates of Akure, Ondo, Nigeria are $7^{\circ} 15^{\prime} 0^{\prime \prime}$ North, $5^{\circ} 12^{\prime} 0^{\prime \prime}$ East at an elevation/altitude of meters. The average elevation of Akure, Nigeria is 353 meters. The time zone id for Akure is Africa/Lagos (GeoNames Geographical Database, 2012).

This data used for this work was obtained at the observatory Unit of the Department of Meteorology, Federal University of Technology, Akure, Ondo State, Nigeria (Fig 1). The parameters taken were: Wind Speed (m/s), Wind Direction (deg), Rainfall (mm), Air Temperature $\left({ }^{\circ} \mathrm{C}\right)$ and Relative Humidity $(\%)$. These were monitored at the site with a Campbell Automatic Weather Station (GRWS100 General Research-Grade Weather Station, Campbell Scientific, Inc.). The data of these parameters were taken at ten minutes interval between July and December 2015. The results were subjected to statistical analyses (Range, mean, SE Mean, Standard Deviation, Coefficient of Variation, Correlation Matrix, and Histogram) using Minitab 16 software.

\section{Results and Discussion}

\subsection{Rainfall}

The means results of the rainfall for the six months are shown in Figs $2-7$. The results ranged from 0 (no rainfall) to $11.60 \mathrm{~mm}$. There were no rainfalls in the months of August and December but there were minimal rain in the months of July, October and November. The results (Table 7) were in agreement with those of Yamazaki et al. (2014) (Japan), Zhang Wu (2013) (USA), Gaita et al. (2014) (Kenya), Xiao et al. (2013) (China), and Sarasamma and Narayana (India). Rain has a scavenging effect when it washes particulate matter out of the atmosphere and dissolves gaseous pollutants. The minimal rainfall obtained within the months of this study may not be enough to washout the pollutant particles around. During high rainfall, air quality is better because particles are removed. It becomes dangerous when the gaseous pollutants at their elevated quantity are dissolved, then it can form acid, which can have serious effects on vegetation, materials and human beings. With the low amount of rainfall recorded in this study, particulate matter (PM) tends to increase (Larssen et al., 2007). 


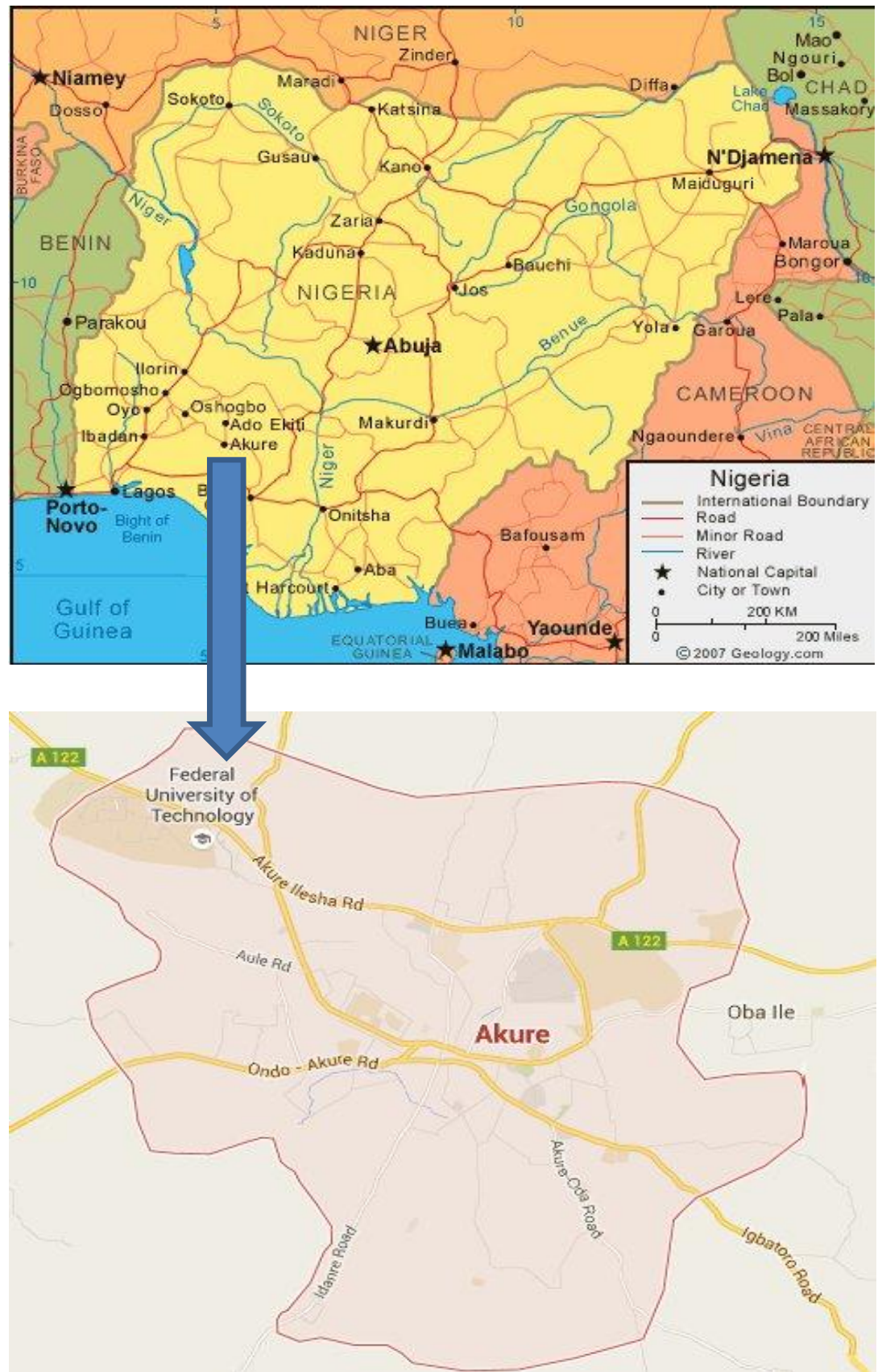

Figure 1. Department of Meteorology, Federal University of Technology, Akure, Ondo State, Nigeria. 


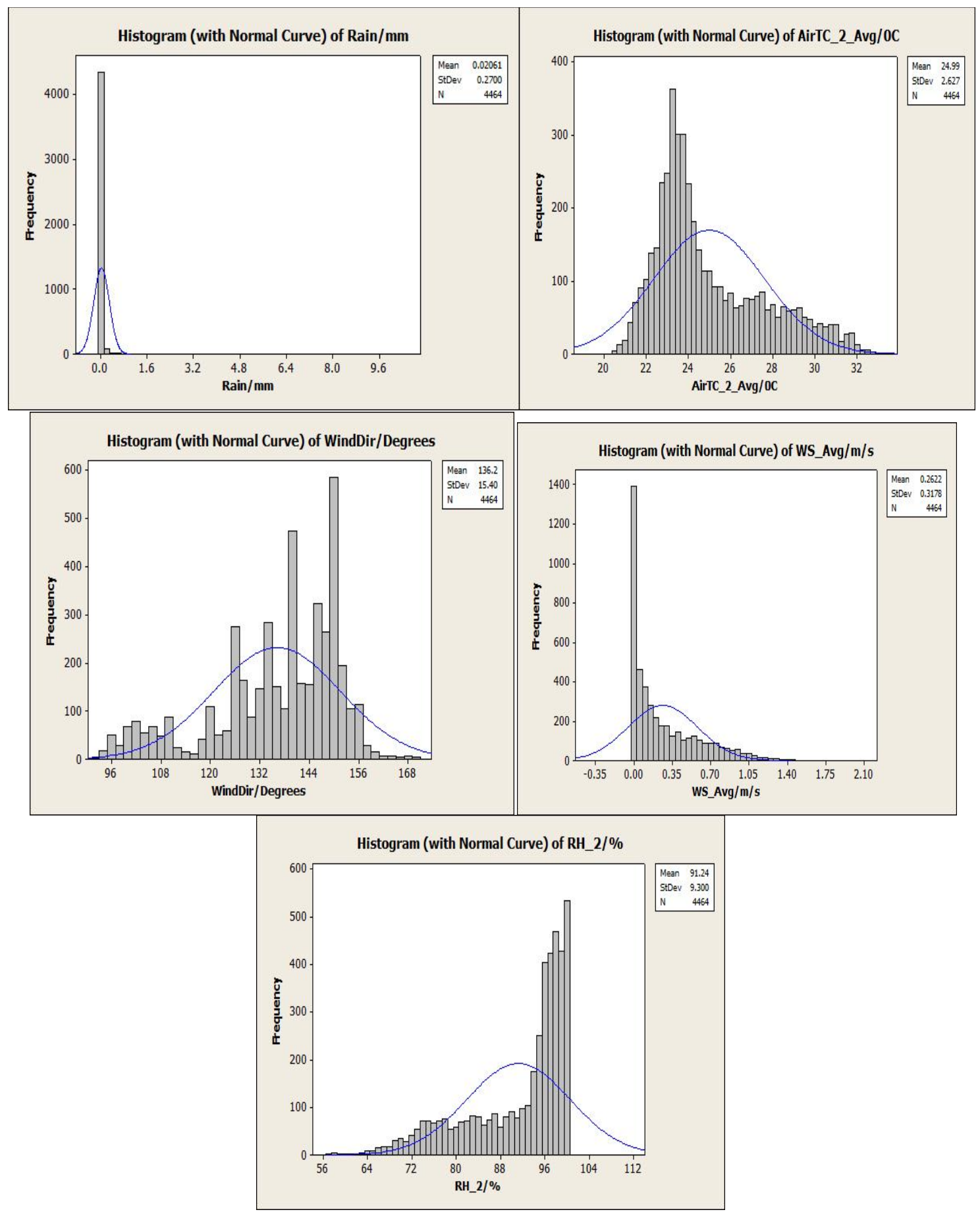

Figure 2. Histogram (with normal curve) of Meteorological Parameters Determined (July). 

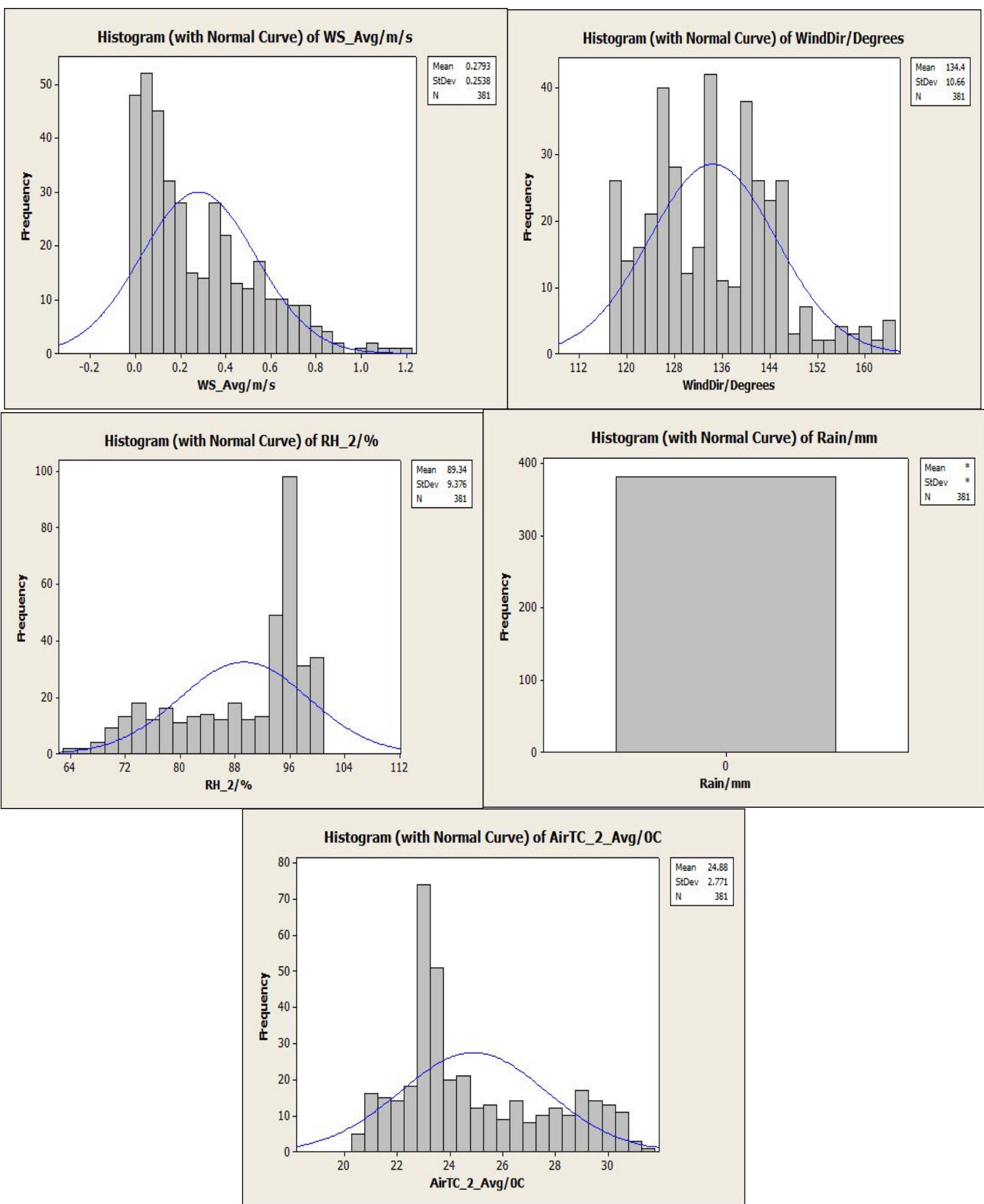

Figure 3. Histogram (with normal curve) of Meteorological Parameters Determined (August). 


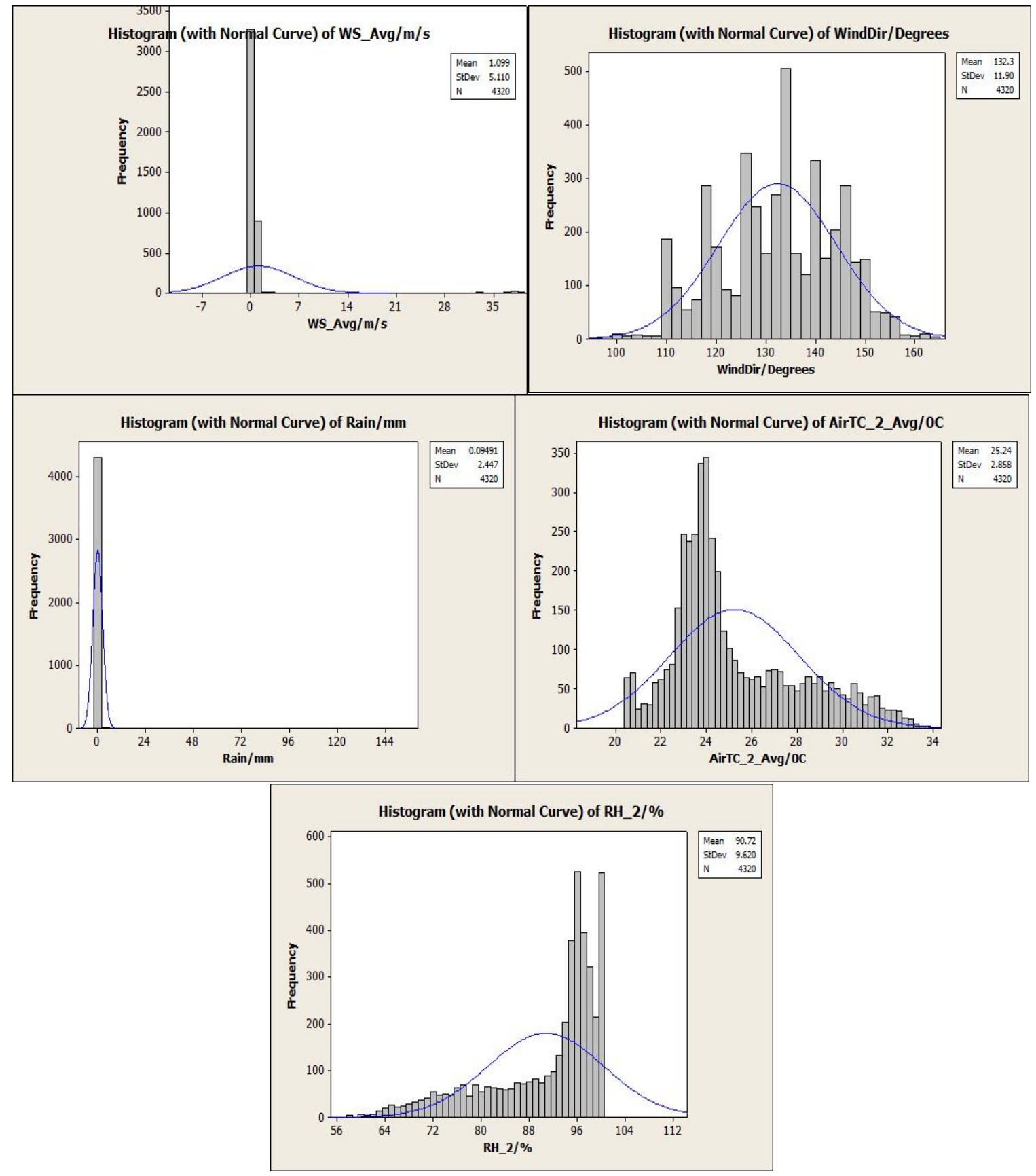

Figure 4. Histogram (with normal curve) of Meteorological Parameters Determined (September). 

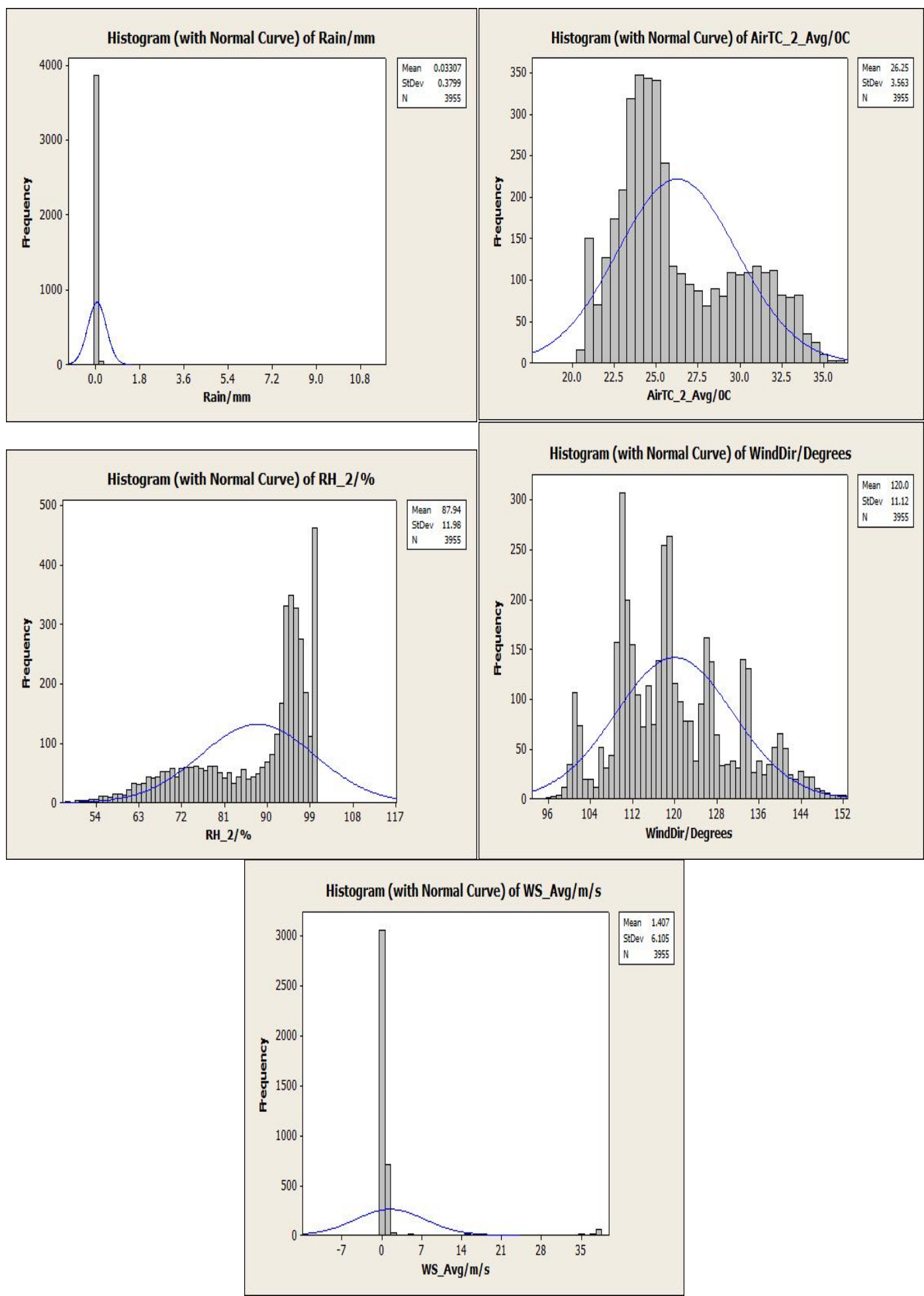

Figure 5. Histogram (with normal curve) of Meteorological Parameters Determined (October). 

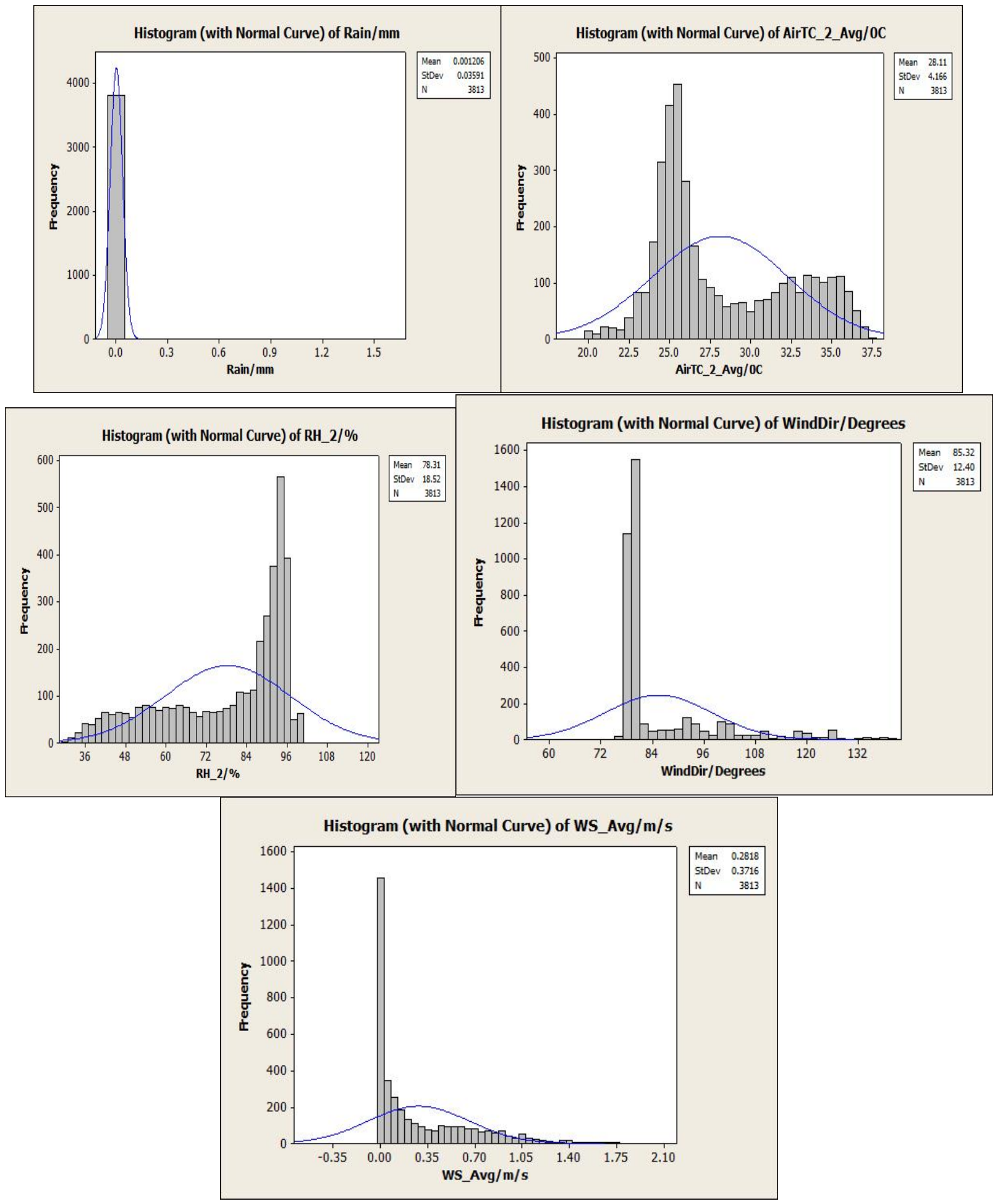

Figure 6. Histogram (with normal curve) of Meteorological Parameters Determined (November). 


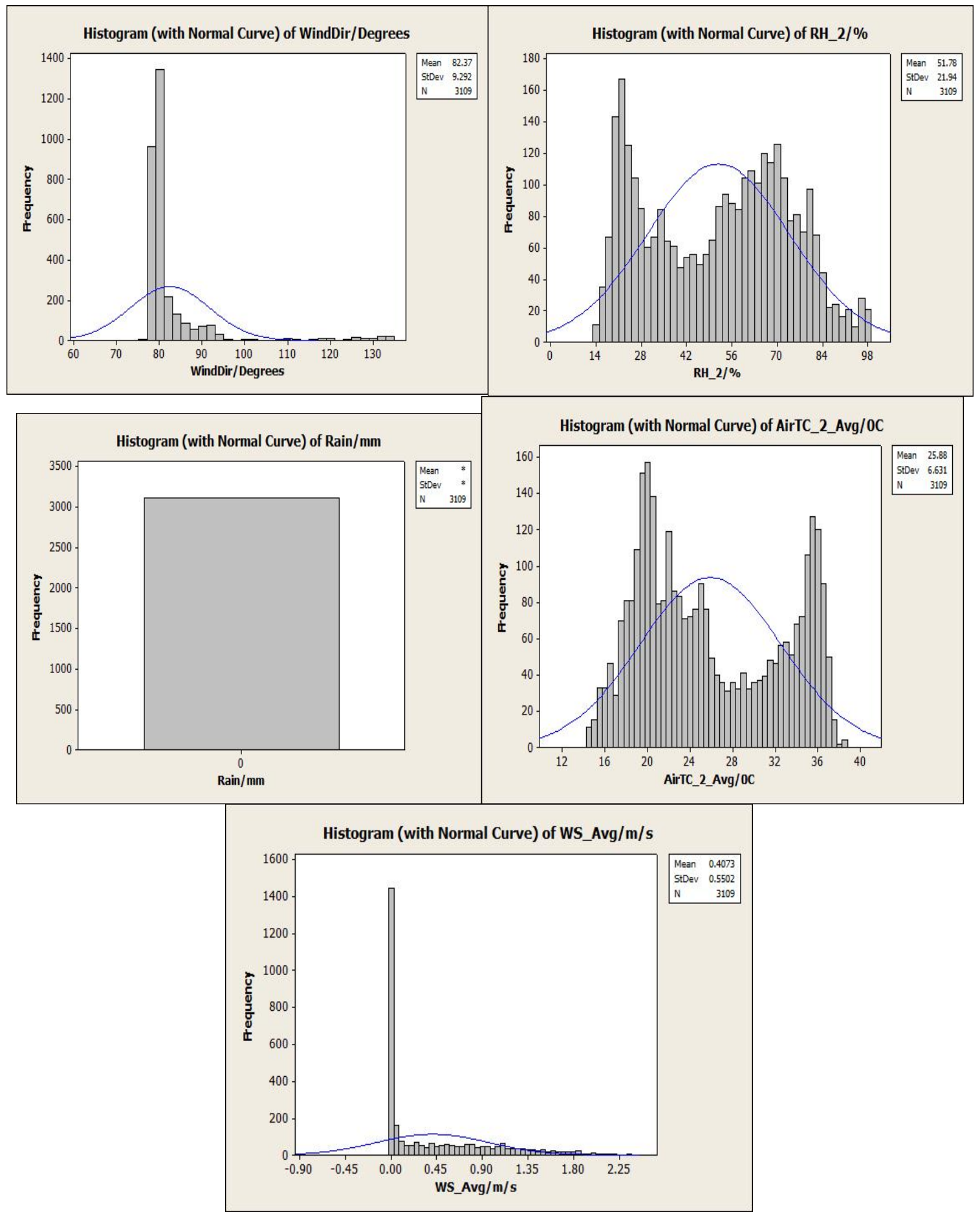

Figure 7. Histogram (with normal curve) of Meteorological Parameters Determined (December). 
Table 1. Basic Description of Meteorological Parameters Determined (July).

\begin{tabular}{lccccc}
\hline Results & $\begin{array}{c}\text { Rain } \\
(\mathrm{mm})\end{array}$ & $\begin{array}{c}\text { Wind } \\
\text { Speed }(\mathrm{ms})\end{array}$ & $\begin{array}{c}\text { Wind } \\
\text { Direction }\left({ }^{\circ}\right)\end{array}$ & $\begin{array}{c}\text { Temperature } \\
\left({ }^{\circ} \mathrm{C}\right)\end{array}$ & $\begin{array}{c}\text { Relative } \\
\text { Humidity }(\%)\end{array}$ \\
\hline Minimum & 0.00 & 0.00 & 92.17 & 24.99 & 55.33 \\
Maximum & 10.80 & 2.16 & 170.03 & 33.60 & 99.99 \\
Mean & 0.02 & 0.26 & 136.19 & 24.99 & 91.24 \\
SE Mean & 0.01 & 0.01 & 0.23 & 0.04 & 0.14 \\
Std Dev & 0.27 & 0.32 & 15.40 & 2.63 & 9.30 \\
Coef Var $(\%)$ & 1310.15 & 121.20 & 11.31 & 10.51 & 10.19 \\
& & & & & \\
\hline
\end{tabular}

Table 2. Basic Description of Meteorological Parameters Determined (August).

\begin{tabular}{llcccc}
\hline Results & $\begin{array}{c}\text { Rain } \\
(\mathrm{mm})\end{array}$ & $\begin{array}{c}\text { Wind } \\
\text { Speed }(\mathrm{ms})\end{array}$ & $\begin{array}{c}\text { Wind } \\
\text { Direction }\left({ }^{\circ}\right)\end{array}$ & $\begin{array}{c}\text { Temperature } \\
\left({ }^{\circ} \mathrm{C}\right)\end{array}$ & $\begin{array}{c}\text { Relative } \\
\text { Humidity }(\%)\end{array}$ \\
\hline Minimum & 0.00 & 0.00 & 117.02 & 20.43 & 64.18 \\
Maximum & 0.00 & 1.19 & 164.77 & 31.35 & 99.99 \\
Mean & 0.00 & 0.28 & 134.36 & 24.88 & 89.34 \\
SE Mean & 0.00 & 0.55 & 0.48 & 0.14 & 0.48 \\
Std Dev & 0.00 & 0.32 & 15.40 & 2.63 & 9.30 \\
Coef Var (\%) & 0.00 & 90.84 & 7.94 & 11.14 & 10.49 \\
& & & & & \\
\hline
\end{tabular}

Table 3. Basic Description of Meteorological Parameters Determined (September).

\begin{tabular}{lrcccc}
\hline Results & $\begin{array}{c}\text { Rain } \\
(\mathrm{mm})\end{array}$ & $\begin{array}{c}\text { Wind } \\
\text { Speed }(\mathrm{ms})\end{array}$ & $\begin{array}{c}\text { Wind } \\
\text { Direction }\left({ }^{\circ}\right)\end{array}$ & $\begin{array}{c}\text { Temperature } \\
\left({ }^{\circ} \mathrm{C}\right)\end{array}$ & $\begin{array}{c}\text { Relative } \\
\text { Humidity }(\%)\end{array}$ \\
\hline Minimum & 0.00 & 0.00 & 96.62 & 20.62 & 56.08 \\
Maximum & 157.20 & 38.79 & 164.69 & 34.03 & 99.99 \\
Mean & 0.10 & 1.09 & 132.33 & 25.24 & 90.72 \\
SE Mean & 0.01 & 0.01 & 0.23 & 0.04 & 0.14 \\
Std Dev & 2.45 & 5.11 & 11.90 & 2.86 & 9.62 \\
Coef Var (\%) & 2578.19 & 465.14 & 8.99 & 11.32 & 10.60 \\
& & & & & \\
\hline
\end{tabular}

Table 4. Basic Description of Meteorological Parameters Determined (October).

\begin{tabular}{lccccc}
\hline Results & $\begin{array}{c}\text { Rain } \\
(\mathrm{mm})\end{array}$ & $\begin{array}{c}\text { Wind } \\
\text { Speed }(\mathrm{ms})\end{array}$ & $\begin{array}{c}\text { Wind } \\
\text { Direction }\left({ }^{\circ}\right)\end{array}$ & $\begin{array}{c}\text { Temperature } \\
\left({ }^{\circ} \mathrm{C}\right)\end{array}$ & $\begin{array}{c}\text { Relative } \\
\text { Humidity }(\%)\end{array}$ \\
\hline Minimum & 0.00 & 0.00 & 76.50 & 19.88 & 30.46 \\
Maximum & 1.60 & 2.14 & 140.38 & 37.49 & 99.99 \\
Mean & 0.02 & 0.26 & 136.19 & 24.99 & 91.24 \\
SE Mean & 0.00 & 0.01 & 0.20 & 0.07 & 0.30 \\
Std Dev & 0.04 & 0.37 & 12.40 & 4.17 & 18.52 \\
Coef Var (\%) & 2976.25 & 131.84 & 14.54 & 14.82 & 23.65 \\
& & & & & \\
\hline
\end{tabular}


Table 5. Basic Description of Meteorological Parameters Determined (November).

\begin{tabular}{lccccc}
\hline Results & $\begin{array}{c}\text { Rain } \\
(\mathrm{mm})\end{array}$ & $\begin{array}{c}\text { Wind } \\
\text { Speed }(\mathrm{ms})\end{array}$ & $\begin{array}{c}\text { Wind } \\
\text { Direction }\left({ }^{\circ}\right)\end{array}$ & $\begin{array}{c}\text { Temperature } \\
\left({ }^{\circ} \mathrm{C}\right)\end{array}$ & $\begin{array}{c}\text { Relative } \\
\text { Humidity }\end{array}$ \\
\hline Minimum & 0.00 & 0.00 & 96.15 & 20.60 & 48.36 \\
Maximum & 11.60 & 38.52 & 151.71 & 36.07 & 99.99 \\
Mean & 0.03 & 1.41 & 119.96 & 26.25 & 87.94 \\
SE Mean & 0.01 & 0.10 & 0.18 & 0.06 & 0.19 \\
Std Dev & 0.38 & 6.11 & 11.12 & 3.56 & 11.98 \\
Coef Var (\%) & 1148.64 & 433.95 & 9.27 & 13.57 & 13.62 \\
\hline
\end{tabular}

Table 6. Basic Description of Meteorological Parameters Determined (December).

\begin{tabular}{lccccc}
\hline Results & $\begin{array}{c}\text { Rain } \\
(\mathrm{mm})\end{array}$ & $\begin{array}{c}\text { Wind } \\
\text { Speed }(\mathrm{ms})\end{array}$ & $\begin{array}{c}\text { Wind } \\
\text { Direction }\left({ }^{\circ}\right)\end{array}$ & $\begin{array}{c}\text { Temperature } \\
\left({ }^{\circ} \mathrm{C}\right)\end{array}$ & $\begin{array}{c}\text { Relative } \\
\text { Humidity }\end{array}$ \\
\hline Minimum & 0.00 & 0.00 & 76.59 & 14.49 & 13.32 \\
Maximum & 0.00 & 2.55 & 135.33 & 38.62 & 98.96 \\
Mean & 0.00 & 0.41 & 82.37 & 25.89 & 51.78 \\
SE Mean & 0.00 & 0.01 & 0.17 & 0.12 & 0.39 \\
Std Dev & 0.00 & 0.55 & 9.29 & 6.63 & 21.94 \\
Coef Var $(\%)$ & 0.00 & 135.09 & 11.28 & 25.62 & 42.37 \\
& & & & & \\
\hline
\end{tabular}

Table 7. Comparison of our results with other studies

\begin{tabular}{|c|c|c|c|c|c|c|}
\hline Parameters & This Study & $\begin{array}{c}\text { Yamazaki et al., } \\
2014 \text { (Japan) }\end{array}$ & $\begin{array}{l}\text { Zhang Wu et. al, } \\
2013 \text { (USA) }\end{array}$ & 1, Gaita et al., & $\begin{array}{c}\text { Xiao et al., } \\
2013 \text { (China) }\end{array}$ & $\begin{array}{l}\text { Sarasamma \& } \\
\text { Narayana (2014) } \\
\text { (India) }\end{array}$ \\
\hline \multicolumn{7}{|l|}{ Rain } \\
\hline July & 0.02 & - & - & - & - & - \\
\hline Aug & 0.00 & & & & & \\
\hline Sept & 0.10 & & & & & \\
\hline Oct & 0.03 & & & & & \\
\hline Nov & 0.02 & & & & & \\
\hline Dec & 0.00 & & & & & \\
\hline \multicolumn{7}{|c|}{ Wind Speed } \\
\hline July & 0.26 & 2.6 & $1.8-2.2$ & 4 & $0.2-1.6$ & $2.0-4.0$ \\
\hline Aug & 0.28 & & & & & \\
\hline Sept & 1.09 & & & & & \\
\hline Oct & 1.41 & & & & & \\
\hline Nov & 0.26 & & & & & \\
\hline Dec & 0.41 & & & & & \\
\hline \multicolumn{7}{|c|}{ Wind Direction } \\
\hline July & 136.19 & - & $149.2-168.2$ & - & - & - \\
\hline Aug & 134.36 & & & & & \\
\hline Sept & 132.33 & & & & & \\
\hline Oct & 119.96 & & & & & \\
\hline Nov & 136.19 & & & & & \\
\hline Dec & 82.37 & & & & & \\
\hline
\end{tabular}




\begin{tabular}{|c|c|c|c|c|c|c|}
\hline \multicolumn{7}{|c|}{ Temperature } \\
\hline July & 24.99 & \multirow[t]{6}{*}{15.5} & \multirow[t]{6}{*}{$6.3-26.7$} & \multirow[t]{6}{*}{20} & \multirow[t]{6}{*}{$-1.5-32.7$} & \multirow[t]{6}{*}{$30-31.89$} \\
\hline Aug & 24.88 & & & & & \\
\hline Sept & 25.24 & & & & & \\
\hline Oct & 26.25 & & & & & \\
\hline Nov & 24.99 & & & & & \\
\hline Dec & 25.89 & & & & & \\
\hline \multicolumn{7}{|c|}{ Relative Humidity } \\
\hline July & 91.24 & \multirow[t]{6}{*}{70.5} & \multirow[t]{6}{*}{$66.2-63.7$} & \multirow[t]{6}{*}{67} & \multirow[t]{6}{*}{$15.2-69.3$} & \multirow[t]{6}{*}{$76.40-77.09$} \\
\hline Aug & 89.34 & & & & & \\
\hline Sept & 90.72 & & & & & \\
\hline Oct & 87.94 & & & & & \\
\hline Nov & 91.24 & & & & & \\
\hline Dec & 51.78 & & & & & \\
\hline Parameter & This Study & $\begin{array}{l}\text { Munir et al., } \\
2013 \text { () } \\
\text { (Saudi Arabia) }\end{array}$ & $\begin{array}{l}\text { Manousakas et al., } \\
2013 \text { (Greece) }\end{array}$ & $\begin{array}{l}\text { Crilley et al., } \\
2014 \\
\text { (Australia) }\end{array}$ & $\begin{array}{r}\text { Abu- Al } \\
\& \text { Abu } \\
2011(\mathrm{Jc}\end{array}$ & $\begin{array}{l}\text { aban } \\
\text { Qudais, } \\
\text { dan) }\end{array}$ \\
\hline \multicolumn{7}{|l|}{ Rain } \\
\hline July & 0.02 & \multirow[t]{6}{*}{0} & \multirow[t]{6}{*}{-} & \multirow[t]{6}{*}{-} & \multirow{6}{*}{\multicolumn{2}{|c|}{$0-25.9$}} \\
\hline Aug & 0.00 & & & & & \\
\hline Sept & 0.10 & & & & & \\
\hline Oct & 0.03 & & & & & \\
\hline Nov & 0.02 & & & & & \\
\hline Dec & 0.00 & & & & & \\
\hline \multicolumn{7}{|c|}{ Wind Speed } \\
\hline July & 0.26 & \multirow[t]{6}{*}{1.15} & \multirow{6}{*}{6} & \multirow{6}{*}{$0.64-4.90$} & $3.2-$ & \\
\hline Aug & 0.28 & & & & & \\
\hline Sept & 1.09 & & & & & \\
\hline Oct & 1.41 & & & & & \\
\hline Nov & 0.26 & & & & & \\
\hline Dec & 0.41 & & & & & \\
\hline Wind Dire & & & & & & \\
\hline July & 136.19 & 239.7 & - & - & - & \\
\hline Aug & 134.36 & & & & & \\
\hline Sept & 132.33 & & & & & \\
\hline Oct & 119.96 & & & & & \\
\hline Nov & 136.19 & & & & & \\
\hline Dec & 82.37 & & & & & \\
\hline Temperat & & & & & & \\
\hline July & 24.99 & 29.5 & $11-16$ & $13-25$ & $8.0-$ & 4.90 \\
\hline Aug & 24.88 & & & & & \\
\hline Sept & 25.24 & & & & & \\
\hline Oct & 26.25 & & & & & \\
\hline Nov & 24.99 & & & & & \\
\hline Dec & 25.89 & & & & & \\
\hline Relative $\mathbf{H}$ & nidity & & & & & \\
\hline July & 91.24 & 34.44 & $23-90$ & $15.2-69.3$ & 39. & -70.3 \\
\hline Aug & 89.34 & & & & & \\
\hline Sept & 90.72 & & & & & \\
\hline Oct & 87.94 & & & & & \\
\hline Nov & 91.24 & & & & & \\
\hline Dec & 51.78 & & & & & \\
\hline
\end{tabular}


Table 8. Correlation Matrix.

\begin{tabular}{|c|c|c|c|c|c|}
\hline & Rain & Wind Speed & $\begin{array}{c}\text { Wind } \\
\text { Direction }\end{array}$ & $\begin{array}{c}\text { Relative } \\
\text { Humidity }\end{array}$ & Temperature \\
\hline \multicolumn{6}{|l|}{ July } \\
\hline Rain & 1 & & & & \\
\hline Wind Speed & 0.023 & 1 & & & \\
\hline Wind Direction & -0.034 & -0.038 & 1 & & \\
\hline Relative Humidity & 0.061 & -0.593 & -0.164 & 1 & \\
\hline Temperature & -0.073 & 0.535 & 0.318 & -0.936 & 1 \\
\hline August & Rain & Wind Speed & $\begin{array}{c}\text { Wind } \\
\text { Direction }\end{array}$ & $\begin{array}{l}\text { Relative } \\
\text { Humidity }\end{array}$ & Temperature \\
\hline Rain & 1 & & & & \\
\hline Wind Speed & * & 1 & & & \\
\hline Wind Direction & $*$ & 0.322 & 1 & & \\
\hline Relative Humidity & $*$ & -0.685 & -0.608 & 1 & \\
\hline Temperature & * & 0.653 & 0.676 & -0.977 & 1 \\
\hline September & Rain & Wind Speed & $\begin{array}{c}\text { Wind } \\
\text { Direction }\end{array}$ & $\begin{array}{c}\text { Relative } \\
\text { Humidity }\end{array}$ & Temperature \\
\hline Rain & 1 & & & & \\
\hline Wind Speed & -0.000 & 1 & & & \\
\hline Wind Direction & -0.016 & 0.128 & 1 & & \\
\hline Relative Humidity & 0.008 & 0.070 & -0.418 & 1 & \\
\hline Temperature & -0.006 & -0.069 & 0.471 & -0.955 & 1 \\
\hline October & Rain & Wind Speed & $\begin{array}{c}\text { Wind } \\
\text { Direction }\end{array}$ & $\begin{array}{c}\text { Relative } \\
\text { Humidity }\end{array}$ & Temperature \\
\hline Rain & 1 & & & & \\
\hline Wind Speed & 0.001 & 1 & & & \\
\hline Wind Direction & -0.039 & 0.055 & 1 & & \\
\hline Relative Humidity & 0.058 & 0.070 & -0.410 & 1 & \\
\hline Temperature & 0.058 & -0.139 & 0.429 & -0.949 & 1 \\
\hline November & Rain & Wind Speed & $\begin{array}{c}\text { Wind } \\
\text { Direction }\end{array}$ & $\begin{array}{c}\text { Relative } \\
\text { Humidity }\end{array}$ & Temperature \\
\hline Rain & 1 & & & & \\
\hline Wind Speed & 0.003 & 1 & & & \\
\hline Wind Direction & 0.002 & -0.053 & 1 & & \\
\hline Relative Humidity & 0.015 & -0.660 & 0.052 & 1 & \\
\hline Temperature & -0.007 & 0.675 & 0.045 & -0.953 & 1 \\
\hline December & Rain & Wind Speed & $\begin{array}{c}\text { Wind } \\
\text { Direction }\end{array}$ & $\begin{array}{l}\text { Relative } \\
\text { Humidity }\end{array}$ & Temperature \\
\hline Rain & 1 & & & & \\
\hline Wind Speed & $*$ & 1 & & & \\
\hline Wind Direction & $*$ & -0.223 & 1 & & \\
\hline Relative Humidity & $*$ & -0.647 & 0.369 & 1 & \\
\hline Temperature & * & 0.633 & -0.460 & -0.851 & 1 \\
\hline
\end{tabular}

\subsection{Wind Speed and Direction}

The mean values of the speed $(\mathrm{m} / \mathrm{s})$ ranged as follows: 0.26, 0.28, 1.09, 1.41, 0.26 and 0.41 (July, August, September, October, November and December respectively), while the month of September had the highest histogram curve and frequency (Fig 4).August, September, November and December periods are calm due to the low means recorded. The correlation matrix (Table 8) showed a weak correlationwith temperature. All others were not correlated (negative).From the results, it could be deduced that the winds are light, it has been shown that pollutants are moved by wind in different directions. Since the wind is light, then there could be poor dispersions of particulate matter in the months of study. Again, due to little lateral wind moving across the wind direction, there could be poor dispersed too. Wind Speed and Direction are used to identify the general direction and the area of the 
emission. When the sources are identified, it assists in reducing the impacts. The wind plays an important role in carrying of dust and soil particles especially during dry season.

\subsection{Temperature}

The temperature recorded for the months were high mostly $>25^{\circ} \mathrm{C}$. The highest value $\left(38.62^{\circ} \mathrm{C}\right)$ and the lowest value $\left(14.49^{\circ} \mathrm{C}\right)$ were observed during the month of December. This is evident in the scanty rainfall throughout the year. The higher the quantity of rainfall, then the lower the temperature, but the reverse is the case. The values of rainfall and relative humidity did not correlate significantly in all the months. Table 7 depicted that only results of Sarasamma and Narayana (2014) (India) were in agreement with the results obtained in this study. All others were below. Hosseinibalam and Hejazi (2012) showed a strong relationship in air pollution $\left(\mathrm{SO}_{2}, \mathrm{O}_{3}, \mathrm{NOx}\right)$ and temperature in study locations in Iran. The differences have shown in the type of weather situation (winter, autumn and spring) from the countries. The results show the high temperature with this, the crops prone to lose water more by evapotranspiration.According to Queensland Government, (2015), measurement of temperature of atmospheric samples supports air quality assessment, air quality modeling and forecasting activities. Temperature and sunlight play an important role in the chemical reactions that occur in the atmosphere to form photochemical smog from other pollutants. While temperature and time have strong correlation (Vijayan et al., 2013). Changes in temperatures have a significant function in determining the agriculture outputs in future.

\subsection{Relative Humidity (RH)}

The mean value of this parameter in all the months ranged from 51.78 to $91.24 \%$ with low standard deviations (Table 1). The variability varied with time (Vijayan et al., 2013). The values showed a decreasing trend with month of December having the least values. The values here were lower thanthe results of other studies from Asia, America, and Africa (Table 7). The differences observed may be due to the different weather conditions. In agreement with Chang et al. (2013) the maximum value of RH was obtained in the nighttime. Tecer et al. (2008) have shown that there was a relationship between RH and air pollution. Since Tecer et al. (2008) depicted the relationship, there could be a relationship between the pollution and RH of the present study area. Humidity (water vapour) plays an important role many chemical reactions (thermal and photochemical) in the atmosphere. As water molecule, it has the ability to attach strongly to many substances anywhere including the atmosphere. Like rainfall I can attach to corrosive gaseswhich can dissolve them to form acid. Acids damage properties, even living things is at health risk. Relative humidity (RH) is the quantity of water vapour in the atmosphere and this is highly variable. RH in the atmosphere depends on geographic allocation, closeness to water bodies, temperature and wind direction. RH is generally high during summer, especially when the rain and temperature are also high.

\section{Conclusion}

From the results obtained from this study, it could be deduced that in the periods of study there was scanty rainfall. The months ofAugust, September, November and December periods are were calm due to the low mean values recorded for wind speed and direction. There were low correlation matrixes between wind speed and directionand temperature. The temperature observed in the study showed the evidence of low rainfall, also, rainfall and relative humidity did not correlate significantly in all the months. The values obtained for RH showed a decreasing trend with month of December having the least values.Generally, the data gathered in this study showed high temperature, humidity, and low rainfall. This conditions could have serious effects on farm produce and health (prevalence of diseases) in terms of poor farm yield, diseased crops/fruits, sickness, rapid spread of diseases (to human, and animal), and other environmental problems.

\section{Acknowledgement}

The authors are grateful to the HOD Department of Meteorology, Federal University of Technology, Akure, Ondo State, Nigeria for allowing us the use of the observatory unitand also to Mr Ladipo for his special assistance in compiling the data.

\section{References}

1. Abu-Allaban M. \& Abu-Qudais H. (2011). Impact assessment of ambient air quality by cement industry: A Case study in Jordan. Aerosol and Air Quality Res. 11:802-810.

2. Chang S-Y., Chou C. C. K., Liu S. \& Zhang Y. (2013). The Characteristics of PM2.5 and Its Chemical Compositions between Different Prevailing Wind Patterns in Guangzhou. Aerosol and Air Quality Research, 13: 1373-1383. 
3. Crilley L. R., Ayoko G. A., Stelcer E., Cohen D. D., Mazaheri M. \& Morawska L. (2014). Elemental Composition of Ambient Fine Particles in Urban Schools: Sources of Children's Exposure. Aerosol and Air Quality Research, 14: 1906-1916.

4. Gaita S. M, Moman J., Gatari M. J., Pettersson J. B. C. \& Janhall S. (2014). Source apportionment and seasonal variation of PM2.5 in a sub-saharan African city: Nairobi Kenya. Atmos. Chem. Phys. 14, 9977-9991.

5. GeoNames Geographical Database(2012). Population of Akure, Nigeria. http://population.mongabay.com/population/nigeria/2350841/akure (Retrieved 9th January, 2016).

6. Hogan C. (2014). Meteorology. Retrieved fromhttp://www.eoearth.org/view/article/154587 (Retrieved 9th January, 2016).

7. Hussain S. S. \& M. Mudasser (2004). Prospects for wheat production under changing climate in mountain areas of Pakistan-An econometric analysis.

8. Hosseinibalam F. \& Hejazi A. (2012). Influence of Meteorological Parameters on Air Pollution in Isfahan. $3^{\text {rd }}$ International Conference on Biology, Environment and Chemistry, IPCBEE vol.46 (2):DOI: 10.7763/IPCBEE.

9. Larssen S.; Barrett K.; Adams A.; van het Bolscher M.; de Leeuw F.; Pulles T.; van Loon M. \& van Pul A. (2007). Air Pollution in Europe 1997-2004.Chemical Coordinating Centre of the European Monitoring and Evaluation Programme,

10. Manousakas M., Eleftheriadis K. \& Papaefthymiou H. (2013). Characterization of PM10 Sources and Ambient Air Concentration Levels at Megalopolis City (Southern Greece) Located in the Vicinity of LigniteFired Plants. Aerosol and Air Quality Research, 13: 804-817.

11. Pratley J. (2003). Principles of Field Crop Production, Oxford University Press, Australia.

12. Queensland Government (2015). Meteorological Factors. The State of Queensland $1995-2015$.

13. Sarasamma J. \& Narayana B. K. (2014). Air Quality Assessment in the surroundings of KMML Industrial Area, Chavara in Kerala, South India. Aerosol and Air Quality Research, 14: 1769-1778, 2014.

14. Tercer L. K, Suren P., Alagha O., Karaca F. \& Tuncel G. (2008). Effect of Meteorological Parameters on Fine and Coarse articulate Matter Mass Concentration in a Coal-Mining Area in Zonguldak, Turkey. Journal of the Air \& Waste Management Association. 58:4, 543-552, DOI: 10.3155/1047-3289.58.4.543

15. Xiao Z., Shao L., Zhang N. \& Wang J. (2013). Heavy Metal Compositions and Bioreactivity ofAirborne PM10 in a Valley-Shaped City in Northwestern China. Aerosol Air Qual. Res. 13: 1116-1125.

16. Vijayan L., Al Thalhi D. F. A. \& Noor D. (2013). Significance of Meteorological Parameters in the Implementation of Agriculture Engineering Practices in and Around Tabuk Region, KSA. International Journal of Applied Science and Technology. 3 (5). 53-65.

17. Wang Z. S., Wu T., Shi G. L., Fu X., Tian Y. Z., Feng Y. C. \& Zhang W. J. (2012). Potential source analysis for $\mathrm{PM}_{10}$ and $\mathrm{PM}_{2.5}$ in autumn in a northern city in China. Aerosol Air Qual. Res, 12(1), 39-48.

18. Yamazaki S., Shima M. \& Yoda Y., (2015). Exposure to air pollution and meteorological factors associated with children's primary care visits at night due to asthma attack: case cross over design for 3-year pooled patients. BMJ Open 2015;5:e005736. doi:10.1136/bmjopen-2014-005736.

19. Yu L., Wang G., Zhang R., Zhang L., Song Y., Wu B., Li X., An K. \& Chu J. (2013). Characterizationand source apportionment of $\mathrm{PM}_{2.5}$ in an urban environment in Beijing. Aerosol and Air QualityRes. 13:574 -583.

20. Zhang Y. \& Wu S.-Y. (2013). Fine Scale Modeling of Agricultural Air Quality over the Southeastern United States using Two Air Quality Models, Part II. Sensitivity Studies and Policy Implications, Aerosol and Air Quality Research, 13(5): 1475-1491. 